\title{
para-Phenylenediamine-induces apoptosis via a pathway dependent on PTK-Ras-Raf-JNK activation but independent of the PI3K/Akt pathway in NRK-52E cells
}

\author{
REENA A.P. KASI ${ }^{1}$, CHYE SOI MOI $^{1}$, YIP WAI KIEN ${ }^{2}$, KOH RHUN YIAN $^{1}$, NG WEI CHIN $^{1}$, \\ NG KHUEN YEN ${ }^{3}$, GNANAJOTHY PONNUDURAI ${ }^{1}$ and SEOW HENG FONG ${ }^{2}$
}

\author{
${ }^{1}$ Department of Human Biology, Cells and Molecules, International Medical University, Kuala Lumpur 57000; \\ ${ }^{2}$ Department of Pathology, Faculty of Medicine and Health Sciences, Universiti Putra Malaysia, Serdang, Selangor 43400; \\ ${ }^{3}$ Jeffrey Cheah School of Medicine and Health Sciences, Monash University \\ Sunway Campus, Bandar Sunway, Selangor 47500, Malaysia
}

Received November 29, 2013; Accepted August 8, 2014

DOI: $10.3892 / \mathrm{mmr} .2014 .2979$

\begin{abstract}
Phenylenediamine ( $p$-PD) is a potential carcinogen, and widely used in marketed hair dye formulations. In the present study, the role of the protein tyrosine kinase (PTK)/Ras/Raf/c-Jun N-terminal kinase (JNK) and phosphoinositide 3-kinase (PI3k)/protein kinase B (Akt) pathways on the growth of NRK-52E cells was investigated. The results demonstrated that $p$-PD reduced cell viability in a dose-dependent manner. The cell death due to apoptosis was confirmed by cell cycle analysis and an Annexin-V-fluorescein isothiocyanate binding assay. Subsequent to staining with 2',7'-dichlorofluorescin diacetate, the treated cells demonstrated a significant increase in reactive oxygen species (ROS) generation compared with the controls. The effects of $p$-PD on the signalling pathways were analysed by western blotting. $p$-PD-treated cells exhibited an upregulated phospho-stress-activated protein kinase/JNK protein expression level and downregulated Ras and Raf protein expression levels; however, Akt, Bcl-2, Bcl-XL and Bad protein expression levels were not significantly altered compared with the control. In conclusion, $p$-PD induced apoptosis by a PTK/Ras/Raf/JNK-dependent pathway and was independent of the PI3K/Akt pathway in NRK-52E cells.
\end{abstract}

\section{Introduction}

para-Phenylenediamine ( $p$-PD) is used in hair dye formulations and it is estimated that two-thirds of the hair dye formulations that are marketed contain $p$-PD (1). Various azo dyes used by

Correspondence to: Dr Chye Soi Moi, Department of Human Biology, Cells and Molecules, International Medical University, 126 Jalan 19/155B, Bukit Jalil, Kuala Lumpur 57000, Malaysia

E-mail: chye_soimoi@imu.edu.my

Key words: para-phenylenediamine, apoptosis, NRK52E cells the industry also contain $p$-PD. Upon azo reduction of these compounds by environmental or intestinal microorganisms, $p$-PD is released. When $p$-PD is ingested, it is absorbed and redistributed to target sites to exert its effects $(2,3)$. Epidemiological studies have indicated that increased usage of permanent hair dye may increase the risk of bladder cancer, non-Hodgkin's lymphoma, multiple myeloma, and haematopoietic cancer $(4,5)$. Besides personal usage, professional hairdressers and dye industry workers are frequently exposed to dyes containing $p$-PD, and epidemiological studies have demonstrated that those who are frequently exposed to this chemical compound have incurred a higher risk of various cancers $(1,4)$. In addition, Sontag $(6)$ demonstrated that the incidence of kidney tumours increased with exposure to $p$-PD in rats. Thus, in the current study, the mechanism by which $p$-PD induces apoptosis in normal rat kidney proximal tubular epithelial (NRK52E) cells was investigated. This cell line is a commonly used cell line for in vitro evaluation of apoptotic pathways. For example, it was demonstrated in NRK52E cells that Numb protects against puromycin aminonucleoside-induced apoptosis by inhibiting the Notch signalling pathway (7). In addition, urografin was demonstrated to induce apoptosis in NRK52E cells via upregulated glucose-regulated protein 78 (GRP78) and GRP94 expression, procaspase-12 cleavage and phosphorylation of protein kinase-like endoplasmic reticulum kinase and eukaryotic initiation factor $2 \alpha(8)$.

Focal adhesion kinase (FAK) phosphorylation is the pivotal integrin-mediated signalling event, since this cytoplasmic tyrosine kinase acts as the scaffold for several effector molecules, such as phosphoinositide 3-kinase $(\mathrm{PI} 3 \mathrm{~K}) /$ protein kinase B (Akt) and the Ras/Raf/c-Jun N-terminal kinase (JNK) cascades $(9,10)$. FAK activation has been associated with survival signals through the activation of the PI3K/Akt and Ras/Raf/JNK pathways $(11,12,13)$. PI3K/Akt is intimately involved in cell survival, as it regulates the activity of several Bcl-2 family members $(14,15,16)$. Protein tyrosine kinases (PTKs) are activated by and form complexes with growth factor receptor-bound protein 2 and Son of sevenless, resulting in activation of Ras, and subsequent activation of the 
Raf and JNK cascade survival pathways $(17,18)$. For example, evodiamine-induced oxidative stress and cell cycle arrest was demonstrated to act through the PTK/Ras/Raf/JNK pathway in HeLa human cervical carcinoma cells (19), and oridonin has been indicated to induce $\mathrm{G}_{2} / \mathrm{M}$ phase cell cycle arrest and apoptosis via inhibition of the PTK/Ras/Raf/JNK survival pathway in L929 murine fibrosarcoma cells (20).

Previous studies have demonstrated that $p$-PD induces apoptosis via p53 in addition to intrinsic and extrinsic pathways in MDCK cells $(21,22)$. Huang et al (23) also demonstrated that $p$-PD induces DNA damage and the expression of mutant p53 and COX-2 proteins in SV-40 immortalized human uroepithelial cells. In the present study, the roles of the PTK/Ras/Raf/JNK and PI3K/Akt signalling pathways on $p$-PD-treated NRK-52E cells was investigated in relation to cell death.

\section{Materials and methods}

Materials. Dulbecco's modified Eagle's medium (DMEM), foetal bovine serum (FBS) and trypsin-EDTA were purchased from Gibco Life Technologies (Grand Island, NY, USA). $p$-PD, dimethyl sulfoxide (DMSO), Triton X-100, Tergitol NP-40, EDTA, Tris-HCl, trypan blue, phosphate-buffered saline (PBS), goat anti-rabbit Immunoglobulin $\mathrm{G}$ horseradish peroxidase (HRP)-conjugated polyclonal secondary antibodies, dithiothreitol (DTT), sodium dodecyl sulphate (SDS), ammonium acetate, Tris-borate-EDTA buffer, Bradford reagent and phenylmethyl sulfonyl fluoride were purchased from Sigma-Aldrich (St. Louis, MO, USA). The Annexin-V-FLUOS Staining kit was purchased from Roche Diagnostics $\mathrm{GmbH}$ (Mannheim, Germany). Proteinase K, ribonuclease A (RNase A) were obtained from BD Pharmingen (San Diego, CA, USA). Rabbit anti-rat monoclonal antibodies for Ras, SAPK-JNK, Akt, Bcl-2, Bcl-xL, Bad, tubulin and phospho SAPK-JNK and mouse anti-rat c-Raf were perchased from Cell Signaling Technology, Inc. (Danvers, MA, USA). Amersham ECL-Plus Western Blotting Reagents and polyvinylidine fluoride (PVDF) membranes were obtained from GE Healthcare Bio-Sciences (Pittsburgh, PA, USA). All of the chemicals were of the highest grade commercially available.

Cell culture and treatment. The NRK-52E normal rat renal tubular epithelial cell line was obtained from the American Type Culture Collection (Manassas, VA, USA). The cells were maintained as a monolayer in DMEM with $2.0 \mathrm{mM}$ L-glutamine adjusted to contain $3.7 \mathrm{~g} / 1$ sodium bicarbonate and $4.5 \mathrm{~g} / 1$ glucose. The medium was supplemented with $1 \%$ penicillin (100 U/ml; Sigma-Aldrich), streptomycin $(10,000 \mu \mathrm{g} / \mathrm{ml}$; Sigma-Aldrich) and $10 \%$ FBS. Cells were cultured in $25-\mathrm{cm}^{2}$ tissue culture-treated flasks at $37^{\circ} \mathrm{C}$ and $5 \% \mathrm{CO}_{2}$ in humidified chambers.

The stock solution of $p$-PD $(100 \mathrm{mg} / \mathrm{ml})$ was dissolved in DMSO and different concentrations were prepared in the culture medium with a final DMSO concentration of $0.1 \%$.

Cell viability assay. The NRK-52E cells were treated with various concentrations of $p$-PD $(50,100,200$ and $300 \mu \mathrm{g} / \mathrm{ml})$, or $0.1 \%$ DMSO for the control, for $24 \mathrm{~h}$ at $37^{\circ} \mathrm{C}$. A trypan blue exclusion protocol was used to determine the cell viability.
Briefly, $\sim 10 \mu \mathrm{l}$ cell suspension in PBS was mixed with $40 \mu \mathrm{l}$ trypan blue, and the numbers of stained (dead cells) and unstained cells (live cells) were examined under a Nikon Eclipse TS-100F inverted microscope (Nikon Corp., Tokyo, Japan) (24).

Cell cycle analysis. The NRK-52E cells were cultured in $25-\mathrm{cm}^{2}$ culture flasks and treated with different concentrations of $p$-PD (50, 100, 200 and $300 \mu \mathrm{g} / \mathrm{ml})$ for $24 \mathrm{~h}$. Subsequent to exposure, the cells were collected, washed with PBS and fixed with ice-cold $70 \%$ ethanol overnight at $4^{\circ} \mathrm{C}$. The cells were washed with PBS, stained with $1 \mathrm{ml}$ fluorochrome solution from the Annexin-V-FLUOS Staining kit [containing $20 \mu \mathrm{g} / \mathrm{ml}$ propidium iodide (PI) and $10 \mu \mathrm{g} / \mathrm{ml}$ RNase A] for $15 \mathrm{~min}$ in dark conditions and analysed using a BD FACSCalibur flow cytometer (E97500679; BD Biosciences, Franklin Lakes, NJ, USA).

Annexin- $V$ staining. The NRK52E cells were cultured in 60-mm tissue-culture dishes. The culture medium was replaced with fresh medium as cells reached $70 \%$ confluence, then different concentrations of $p$-PD (50, 100, 200 and $300 \mu \mathrm{g} / \mathrm{ml}$ ) were added prior to $24-\mathrm{h}$ culture. Levels of apoptosis were determined by staining with the Annexin-V kit (25). Following incubation, floating or adherent cells that were later trypsinised were pooled and centrifuged for $5 \mathrm{~min}$ at $1,000 \mathrm{x}$ g. Pelleted cells were washed with PBS. Next, cells were centrifuged for $5 \mathrm{~min}$ at 1,000 $\mathrm{x} \mathrm{g}$ and resuspended in $100 \mu \mathrm{l}$ Annexin-V-Fluos and PI labelling solution (from the Annexin-V kit) for $10 \mathrm{~min}$. The stained cells were analysed by flow cytometry, where the fluorescence emission was measured at $530 \mathrm{~nm}$. The percentage cell apoptosis was calculated using BD Multiset $^{\mathrm{TM}}$ 2.2, BD FACStation ${ }^{\mathrm{TM}}$ 5.2.1, ModFit LT 3.0 and CellQuest software (BD Biosciences).

Detection of intracellular reactive oxygen species (ROS). The NRK52E cells were treated with $100 \mu \mathrm{g} / \mathrm{ml} p$-PD for 1,2 or $3 \mathrm{~h}$, and controls were treated with $0.1 \%$ DMSO. All cells were stained with $10 \mu \mathrm{M}$ 2',7'-dichlorofluorescin diacetate (DCFH-DA; Sigma-Aldrich) for $30 \mathrm{~min}$. Subsequent to washing with PBS, the fluorescence intensity was detected by a Tecan Infinite 200 PRO fluorescence plate reader (Tecan Group Ltd., Maennedorf, Switzerland) with excitation and emission wavelengths of 488 and $525 \mathrm{~nm}$, respectively.

Western blot analysis. Western blot analysis was performed according to the methods of a previous study (26). The culture medium was replaced with fresh medium as cells reached $70 \%$ confluence, then different concentrations of $p$-PD (50, 100,200 and $300 \mu \mathrm{g} / \mathrm{ml}$ ) were added and cells were cultured for $24 \mathrm{~h}$. Next, adherent and floating cells were collected and homogenised in a lysis buffer $(10 \mathrm{mM}$ Tris- $\mathrm{HCl}, \mathrm{pH} 8.0$; $0.32 \mathrm{mM}$ sucrose; $5 \mathrm{mM}$ EDTA; $2 \mathrm{mM}$ DTT; $1 \mathrm{mM}$ phenylmethyl sulfonyl fluoride; and 1\% Triton X-100) and centrifuged at 10,621 x g (5427R; Eppendorf, Hamburg, Germany) for $10 \mathrm{~min}$. The supernatants were collected and assayed for protein concentration using the Bradford protein assay method (27). An equal quantity of protein per sample was subjected to $10 \%$ SDS-polyacrylamide gel electrophoresis. Following electrophoresis, the proteins were transferred to the PVDF membranes by electroblotting and incubated with diluted primary antibodies 


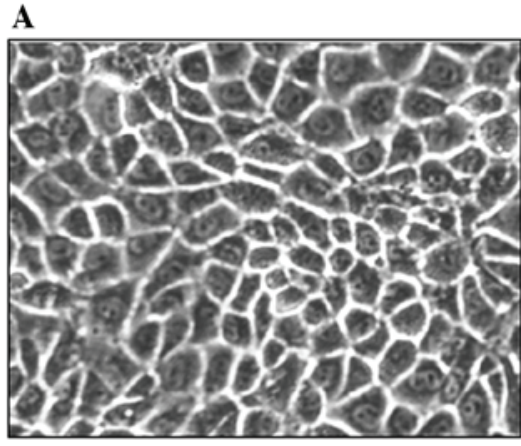

Control
B

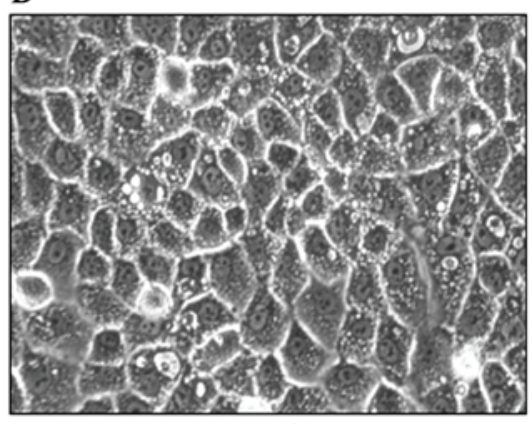

$50 \mu \mathrm{g} / \mathrm{ml}$

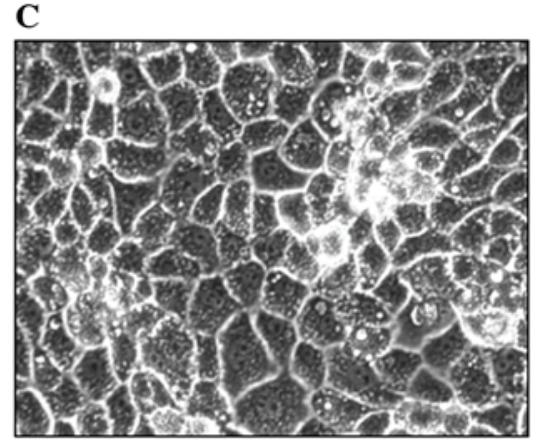

$100 \mu \mathrm{g} / \mathrm{ml}$



$200 \mu \mathrm{g} / \mathrm{ml}$

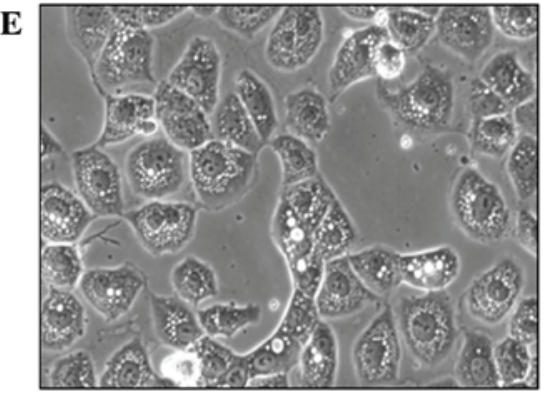

$300 \mu \mathrm{g} / \mathrm{ml}$

Figure 1. Effects of $p$-PD on cell morphology in NRK52E cells. NRK52E cells were treated with (A) DMSO or $p$-PD at a concentration of (B) 50, (C) 100, (D) 200 and (E) $300 \mu \mathrm{g} / \mathrm{ml}$ for $24 \mathrm{~h}$. The results were observed under an inverted microscope; magnification, $\mathrm{x} 200$. $p$-PD, para-phenylenediamine; DMSO, dimethyl sulfoxide.

for $1 \mathrm{~h}$ at $25^{\circ} \mathrm{C}$. The membranes were washed, incubated for $30 \mathrm{~min}$ at $25^{\circ} \mathrm{C}$ with the HRP-conjugated secondary antibodies and subsequently washed extensively prior to detection by chemiluminescence with the ECL-Plus kit. The proteins were visualised by exposing the blots to film (Kodak, Rochester, NY, USA). The western blot data were quantified using Image J software (http://imagej.nih.gov/ij/).

Statistical analysis. Results are expressed as the mean \pm standard deviation from at least three independent experiments. Statistical analysis was performed using Student's t-test. ${ }^{*} \mathrm{P}<0.05$ was considered to indicate a statistically significant difference. The error bars denote standard deviation.

\section{Results}

p-PD alters cell morphology. The NRK-52E cells were treated with four different concentrations of $p$-PD $(50,100$, 200 and $300 \mu \mathrm{g} / \mathrm{ml}$ ) for $24 \mathrm{~h}$, then observed under an inverted microscope. The control cells retained their normal, clear plasma membrane. There was a uniform cell distribution with neighbouring cells closely connected to each other and clear cell nuclei (Fig. 1A). Following $p$-PD treatment, the cells were enlarged, forming a variety of shapes and sizes. The cells lost contact with neighbouring cells and cytoplasmic vacuolisation occurred (Fig. 1B and C). In addition, cell shrinkage and blebbing of the plasma membrane were also observed at higher $p$-PD concentrations (Fig. 1D and E).

$p$ - $P D$ reduces cell viability. The cell viability of $p$-PD-treated NRK-52E cells was examined with a trypan blue exclusion

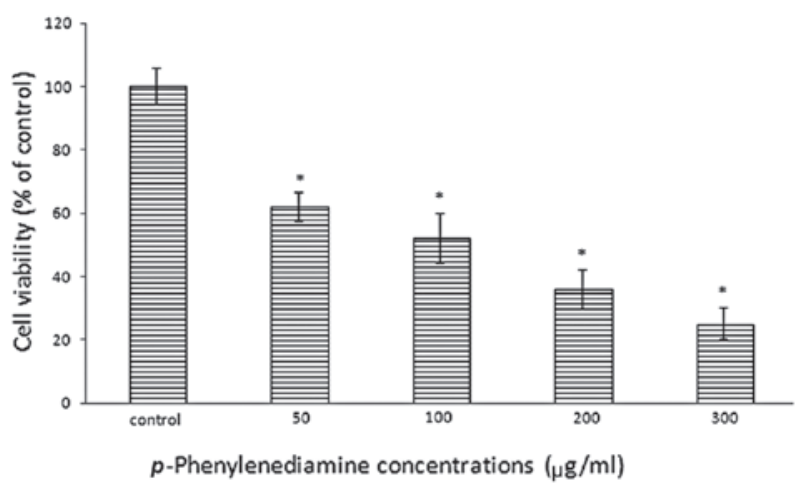

Figure 2. Effect of $p$-PD on cell viability in NRK52E cells, evaluated by a trypan blue exclusion assay. NRK52E cells were treated with different doses of $p$-PD $(50,100,200$ and $300 \mu \mathrm{g} / \mathrm{ml})$ for $24 \mathrm{~h}$. Data are presented as the mean \pm standard deviation and are representative of three independent experiments. ${ }^{*} \mathrm{P}<0.05$ vs. the control group. $p$ - $\mathrm{PD}$, para-phenylenediamine.

assay subsequent to a $24 \mathrm{~h}$ incubation period. The results demonstrated reduced cell viability in NRK-52E cells that were treated with $p$-PD; and as the concentration increased, cell viability reduced. Treatments of 50, 100, 200 and $300 \mu \mathrm{g} / \mathrm{ml}$ led to cell viabilities of $62.2,52.5,36.8$ and $25.4 \%$ of the control (Fig. 2), respectively.

p-PD alters cell cycle progression and inhibits mitosis. p-PD was previously demonstrated to induce cell death. To determine the nature of the cell death (necrotic or apoptotic) changes in the DNA content of the $p$-PD-treated cells were detected using the PI staining method. The cell cycle results indicated that the cell cycle distribution of control cells was as follows: $0.64 \pm 0.01 \%$ in 

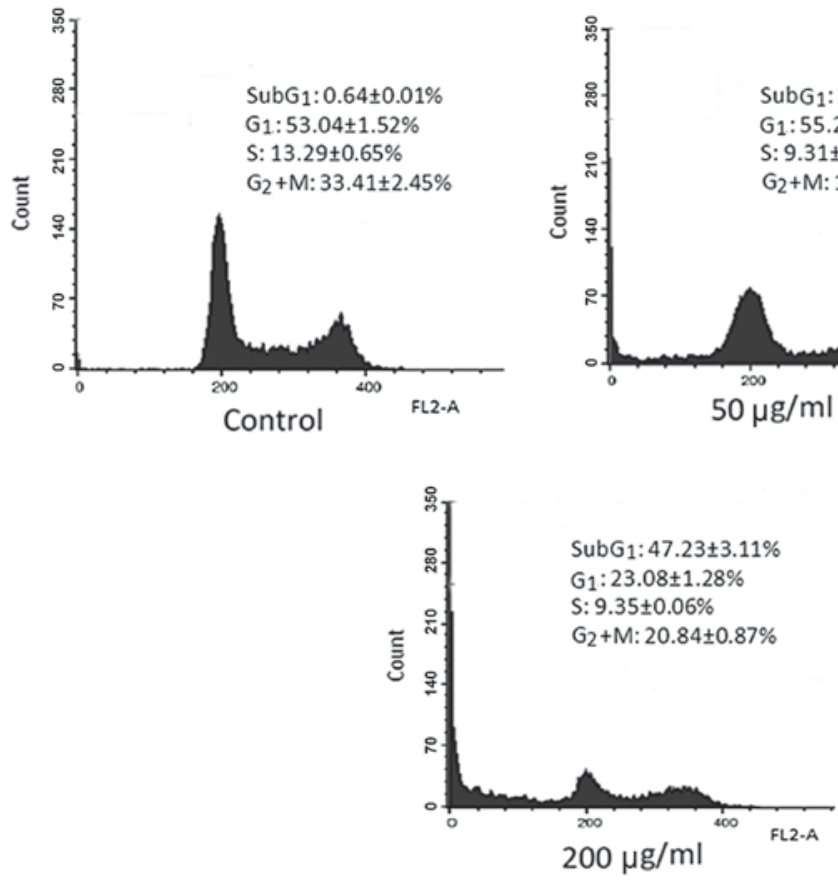

SubG $1: 20.99 \pm 0.89 \%$ $G_{1}: 55.25 \pm 1.32 \%$ S: $9.31 \pm 0.05 \%$


Figure 3. Effect of $p$-PD on cell cycle distributions in NRK52E cells. Cells were treated with different doses of $p$-PD (50, 100, $200 \mathrm{and} 300 \mu \mathrm{g} / \mathrm{ml})$ for $24 \mathrm{~h}$. Following staining with PI, the cell cycle was analysed by flow cytometry. The percentages of cells in the sub $\mathrm{G}_{1}, \mathrm{G}_{1}, \mathrm{~S}$ and $\mathrm{G}_{2}+\mathrm{M}$ phases following treatment with various doses of $p$-PD are presented as cumulative data from three independent experiments. $p$-PD, para-phenylenediamine; PI, propidium iodide.

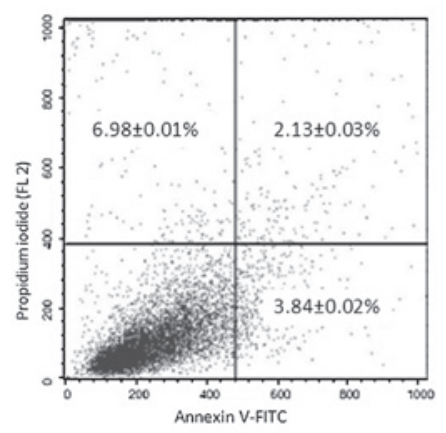

Control



$50 \mu \mathrm{g} / \mathrm{ml}$



$100 \mu \mathrm{g} / \mathrm{ml}$



$200 \mu \mathrm{g} / \mathrm{ml}$

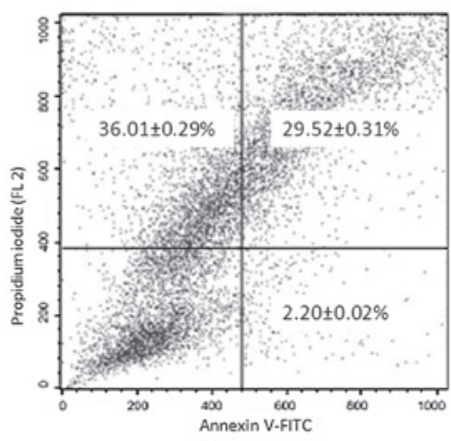

$300 \mu \mathrm{g} / \mathrm{ml}$

Figure 4. Effect of $p$-PD on apoptosis in NRK52E cells. Cells were treated with different doses of $p$-PD (50, 100,200 and $300 \mu \mathrm{g} / \mathrm{ml})$ for 24 h. Following staining with Annexin-V and PI, levels of apoptosis were analysed by flow cytometry. The cumulative data are from three independent experiments. $p$-PD, para-phenylenediamine; PI, propidium iodide; ; FITC, fluorescien isothiocyanate.

the sub- $\mathrm{G}_{1}$ phase; $53.04 \pm 1.52 \%$ in the $\mathrm{G}_{1}$ phase; $13.29 \pm 0.65 \%$ in the $S$ phase; and $33.41 \pm 2.45 \%$ in the $\mathrm{G}_{2}+\mathrm{M}$ phase.

In cells exposed to $50 \mu \mathrm{g} / \mathrm{ml} p$-PD, the percentage of cells in the sub $-\mathrm{G}_{1}$ phase increased to $20.99 \pm 0.89 \%$, compared with
$34.02 \pm 0.45 \%$ following exposure to $100 \mu \mathrm{g} / \mathrm{ml} p$-PD. When the $p$-PD concentrations increased to 200 and $300 \mu \mathrm{g} / \mathrm{ml}$, the percentages of cells in the sub- $G_{1}$ phase further increased to $47.23 \pm 3.11$ and $76.74 \pm 2.45 \%$, respectively (Fig. 3). 


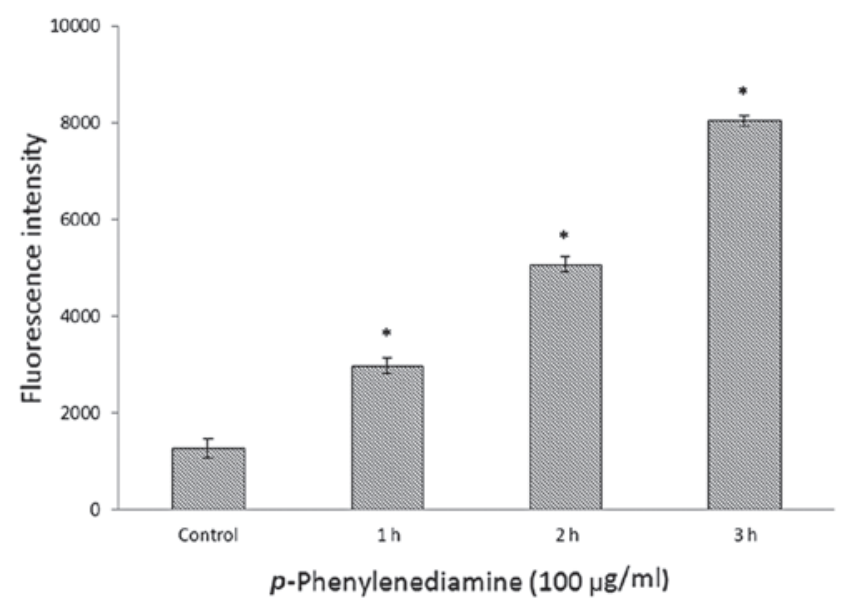

Figure 5. Effect of $p$-PD on ROS generation in NRK52E cells. NRK52E cells were treated with $100 \mu \mathrm{g} / \mathrm{ml} p$-PD for 1,2 and $3 \mathrm{~h}$. ROS generation was indicated by DCFH-DA fluorescence. The fluorescence intensity levels were detected using a fluorescence plate reader at excitation and emission wavelengths of $488 \mathrm{~nm}$ and $525 \mathrm{~nm}$, respectively. The fluorescence intensity in cells treated with various doses of $p$-PD is presented as cumulative data from three independent experiments ( $\mathrm{P}<0.05$ vs. control). $p$-PD, para-phenylenediamine.

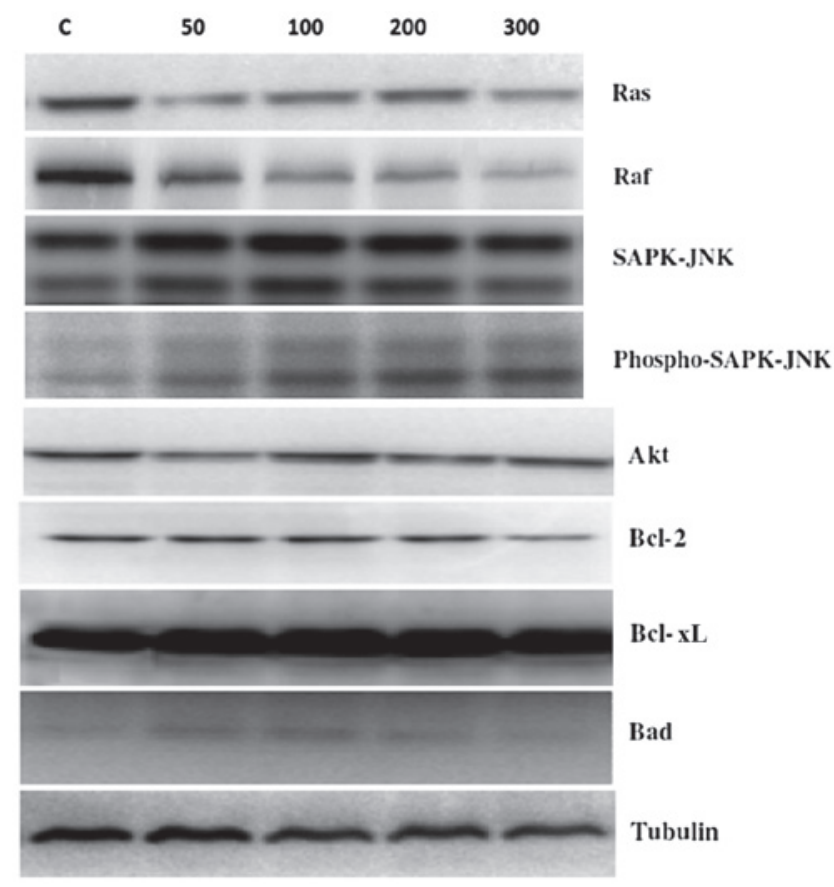

Figure 6. Effects of $p$-PD on signalling pathways in NRK52E cells. NRK52E cells were treated with different doses of $p$-PD $(50,100,200$ and $300 \mu \mathrm{g} / \mathrm{ml})$ for $24 \mathrm{~h}$. The protein expression levels of Ras, Raf, SAPK-JNK, Akt, Bcl-2, $\mathrm{Bcl}-\mathrm{xL}$ and $\mathrm{Bad}$ were evaluated by western blot analysis. $p$-PD, para-phenylenediamine; SAPK, stress-activated protein kinase; JNK, c-Jun N-terminal kinase Akt, protein kinase B.

$p$-PD also induced a reduction in the numbers of cells in the $\mathrm{G}_{2}+\mathrm{M}$ phase compared with the control cells. Compared with $33.41 \pm 2.45 \%$ in the control cells, the cells treated with $p$-PD at concentrations of 50,100, 200 and $300 \mu \mathrm{g} / \mathrm{ml}$ presented $14.92 \pm 0.98,20.76 \pm 1.02,20.84 \pm 0.87$ and $9.46 \pm 0.06 \%$ of cells in the $\mathrm{G}_{2}+\mathrm{M}$ phase, respectively. This result demonstrates a reduction in mitosis in the treated cells compared with the control cells (Fig. 3).
Annexin-V staining and flow cytometry. The induction of apoptosis by $p$-PD was further confirmed by Annexin-V staining. Following incubation with $p$-PD at a concentration of $50,100,200$ or $300 \mu \mathrm{g} / \mathrm{ml}$ for $24 \mathrm{~h}$, the percentages of Annexin $\mathrm{V}^{+} / \mathrm{PI}^{+}$cells increased to $8.47 \pm 0.04,15.05 \pm 0.08$, $25.01 \pm 0.14$ and $29.52 \pm 0.31 \%$, respectively, compared with the control group $(2.13 \pm 0.03 \%)$. Additionally, Annexin $\mathrm{V}^{+} / \mathrm{PI}^{-}$cells were also increased to $12.95 \pm 0.02,16.10 \pm 0.05,15.87 \pm 0.05$ and $36.01 \pm 0.29 \%$, respectively, compared with the control group $(6.98 \pm 0.01 \%)$ (Fig. 4).

p-PD induces intracellular ROS generation. The effects of $p$-PD on the production of intracellular ROS were examined following DCFH-DA staining. The control cells exhibited low-level ROS generation (Fig. 5), and the cells treated with $100 \mu \mathrm{g} / \mathrm{ml} p$-PD for $1 \mathrm{~h}$ presented a ROS level twice as high as controls. Following 2-h treatment, the ROS level had increased four-fold compared with the control cells. The intracellular ROS level increased markedly in the cells that were treated with $100 \mu \mathrm{g} / \mathrm{ml} p$-PD for $3 \mathrm{~h}$ (Fig. 5).

Effects of p-PD on the protein expression levels of Ras, Raf, SAPK-JNK, Akt, Bcl-2, Bcl-xL and Bad. To assess the molecular mechanism underlying $p$-PD-induced apoptosis, the expression levels of the survival proteins Ras, Raf, Bcl-2 and $\mathrm{Bcl}-\mathrm{XL}$ were assessed at $24 \mathrm{~h}$ following $p$-PD treatments of $50,100,200$ and $300 \mu \mathrm{g} / \mathrm{ml}$. The results demonstrated that the expression levels of the Ras and Raf survival proteins were reduced by $p$-PD in a dose-dependent manner (Fig. 6). However, Akt, Bcl-2 and Bcl-xL protein expression levels were not markedly altered compared with controls.

With regards to the apoptotic proteins, SAPK-JNK expression level was not markedly altered, and the phosphorylated SAPK-JNK expression levels markedly increased as $p$-PD concentrations increased (Fig. 6). In addition, $p$-PD had no effect on the Bad expression level with $p$-PD treatment, compared with the control cells. Tubulin was used as a loading control.

\section{Discussion}

Carcinogenesis is a process resulting from genetic alterations leading to mutations of oncogenes or tumour suppressor genes that drive the progressive transformation of normal cells into malignant cells $(28,29)$. At the molecular level, genetic mutations are able to alter translated proteins and thereby disrupt downstream signalling pathways that are essential for apoptosis, cell cycle and other cellular processes $(30,31)$. Cadmium, a causative agent in various types of cancer, elevates intracellular free calcium ion ([ $\left.\left.\mathrm{Ca}^{2+}\right] \mathrm{i}\right)$ levels, leading to neuronal apoptosis partly by activating mitogen-activated protein kinases (MAPK) and mammalian target of rapamycin pathways (32). Additionally, cadmium exposure leads to the induction of the ERK signalling pathway, which alters gene expression in osteoblasts, and apoptotic death in Saos-2 cells (33). Chronic exposure to arsenic can lead to the development of various types of cancer; it downregulates Akt and c-Fos protein expression, and induces apoptosis in glutathione-deficient cells (34).

$p$-PD is a potential carcinogen that is widely used in permanent hair dye $(35,36)$, and it has been reported that inci- 
dences of kidney tumours increase in rats following exposure to $p$-PD (6). Therefore, in the present study, the molecular mechanism underlying $p$-PD-induced apoptosis was investigated in NRK-52E cells, and to the best of our knowledge, it was demonstrated for the first time that $p$-PD-induces cell death in a dose-dependent manner in NRK-52E cells (Fig. 2). It was confirmed that this cell death was due to apoptosis, as indicated in Fig. 3. Cell cycle analysis demonstrated a reduction in the number of cells in the $\mathrm{G}_{2}+\mathrm{M}$ phase in addition to an increase in the number of cells in the sub- $G_{1}$ phase in the treated cells, when compared with the respective percentages in the control group. This finding indicates that $p$-PD induced cell cycle arrest. In addition, Annexin-V staining demonstrated that the number of apoptotic cells increased following $p$-PD exposure in a dose-dependent manner (Fig. 4). In previous studies, it has been established that oxidised $p$-PD induces the production of ROS, leading to an imbalance between production and the removal of ROS and overwhelming oxidative stress that eventually induces apoptosis $(37,38)$.

ROS generated primarily by the mitochondria are highly reactive metabolites that are produced during normal cell metabolism (39). Curtin et al (40) reported that the increases in intracellular ROS levels may lead to apoptosis. The underlying mechanism may involve the direct interaction and destruction of cellular proteins, lipids and DNA, and/or indirect interference with normal cellular signalling pathways and gene regulation (41). Consistent with these findings, the present results demonstrated that intracellular ROS levels increased significantly in the $p$-PD-treated NRK-52E cells in a dose-dependent manner (Fig. 5). High levels of intracellular ROS cause disruption of the mitochondrial membrane potential, release of cytochrome $c$ with subsequent activation of the caspase cascade and ultimately, programmed cell death $(42,43)$. Additionally, intracellular ROS can catalytically inactivate protein tyrosine phosphatases through the oxidation of active-site cysteine residues, which negatively regulate receptor tyrosine kinase (RTK) activity and downstream signalling, and hence allow sustained PTK phosphorylation and activation (44).

PTKs serve a key role in the transmission of various signals from cell-surface receptors to the nucleus. PTKs can be divided into the transmembrane (T)RTKs and non-RTKs (45). Ras links RTKs and non-RTKs to downstream serine/threonine kinases, including the MAPKs (46). The activation of the Ras/Raf/MAPK pathway has been demonstrated to induce growth arrest in several cell types. Oridonin induces apoptosis in L929 cells through inhibition of the PTK/Ras/Raf/JNK pathway (20). In addition,PKT/Ras/Raf/JNK inhibition-derived ROS/NO production contributed to $\mathrm{G} 2 / \mathrm{M}$ phase cell cycle arrest in evodiamine-treated human cervix carcinoma HeLa cells (19). Consistent with these findings, in the current study it was demonstrated that the Ras/Raf/JNK pathway is able to promote apoptosis by inducing $p$-PD in NRK52E cells. Additionally, anti-carcinogenic compounds, UV- and gamma-irradiation have previously been indicated to induce apoptosis via a JNK-dependent pathway (47-50).

Oxidative stress stimulates multiple intracellular signal transduction pathways such as Akt-Bad. Akt, which is downstream of PI3K, regulates mechanically driven and receptor-ligand signalling (51). Activation of the PI3K/Akt can lead to Bad phosphorylation at specific serine residues. Phosphorylated Bad binds 14-3-3 $\zeta$ proteins in the cytosol that sequester and tag Bad for subsequent degradation (52). Alternatively, pro-apoptotic proteins can be retained in the cytosol by binding to anti-apoptotic proteins, such as Bcl-2 and Bcl-xL (53). An increase in $\mathrm{Bcl}-2$ and $\mathrm{Bcl}-\mathrm{xL}$ expression prevents cytochrome $c$ release from the mitochondria, thereby inhibiting activation of caspases, such as caspase- 9 and caspase-3, and preventing apoptosis $(54,55)$. In the present study, it was demonstrated that there were no changes in the levels of Bcl-2, Bcl-xL and Bad proteins compared with controls (Fig. 7). These findings suggest that the molecular mechanism triggered by $p$-PD-induced cell death is independent of the PI3K/Akt/Bad pathway.

In conclusion, the results of the present study demonstrated that $p$-PD induced apoptosis in NRK52E cells; in addition, DCFH-DA staining confirmed that apoptosis was induced due to oxidative stress. Furthermore, the results indicated that $p$-PD induced apoptosis via the PTK-Ras-Raf-JNK pathway, which upregulated SAPK/JNK protein expression levels and downregulated Ras and Raf protein expression levels. However, $p$-PD was found to induce apoptosis independent of PI3K/Akt pathway, as Akt, Bcl-2, Bcl-XL and Bad protein expression levels were not significantly altered compared with the control. Future studies are required in order to further elucidate the role of $p$-PD in tumorigenesis.

\section{Acknowledgements}

The present study was supported by grants FRGS/2/2010/ST/IMU/03/1(SKK) from Jabatan Pengajian Tinggi Malaysia and BMS 102-2010 (10) from the International Medical University, Kuala Lumpur, Malaysia.

\section{References}

1. Gago-Dominguez M, Castelao JE, Yuan JM, Yu MC and Ross RK: Use of permanent hair dyes and bladder-cancer risk. Int J Cancer 91: 575-579, 2001.

2. Chung KT and Stevens SE Jr: Degradation of azo dyes by environmental microorganisms and helminths. Environ Toxicol Chem 12: 2121-2132, 1993.

3. Chung KT, Stevens SE Jr and Cerniglia CE: The reduction of azo dyes by the intestinal microflora. Crit Rev Microbiol 18: 175-190, 1992.

4. Thun MJ, Altekruse SF, Namboodiri MM, Calle EE, Myers DG and Heath CW Jr: Hair dye use and risk of fatal cancers in US women. J Natl Cancer Inst 86: 210-215, 1994.

5. Rauscher GH, Shore D and Sandler DP: Hair dye use and risk of adult acute leukemia. Am J Epidemiol 160: 19-25, 2004.

6. Sontag JM: Carcinogenicity of substituted-benzenediamines (phenylenediamines) in rats and mice. J Natl Cancer Inst 66: 591-602, 1981.

7. Ding X, Zhu F, Li T, Zhou Q, Hou FF and Nie J: Numb protects renal proximal tubular cells from puromycin aminonucleoside-induced apoptosis through inhibiting Notch signaling pathway. Int J Biol Sci 7: 269-278, 2011.

8. Wu CT, Sheu ML, Tsai KS, Weng TI, Chiang CK and Liu SH: The role of endoplasmic reticulum stress-related unfolded protein response in the radiocontrast medium-induced renal tubular cell injury. Toxicol Sci 114: 295-301, 2010.

9. Stupack DG and Cheresh DA: Get a ligand, get a life: integrins, signaling and cell survival. J Cell Sci 115: 3729-3738, 2002.

10. Guan JL and Shalloway D: Regulation of focal adhesion-associated protein tyrosine kinase by both cellular adhesion and oncogenic transformation. Nature 358: 690-692, 1992.

11. Frisch SM, Vuori K, Ruoslahti E and Chan-Hui PY: Control of adhesion-dependent cell survival by focal adhesion kinase. J Cell Biol 134: 793-799, 1996. 
12. Gilmore AP, Metcalfe AD, Romer $\mathrm{LH}$ and Streuli $\mathrm{CH}$ Integrin-mediated survival signals regulate the apoptotic function of Bax through its conformation and subcellular localization. J Cell Biol 149: 431-446, 2000.

13. Zhao JH, Reiske H and Guan JL: Regulation of the cell cycle by focal adhesion kinase. J Cell Biol 143: 1997-2008, 1998

14. Kurenova E, Xu LH, Yang X, Baldwin AS Jr, et al: Focal adhesion kinase suppresses apoptosis by binding to the death domain of receptor-interacting protein. Mol Cell Biol 24: 4361-4371, 2004.

15. Leverrier Y, Thomas J, Mathieu AL, Low W, Blanquier B and Marvel J: Role of PI3-kinase in Bcl-X induction and apoptosis inhibition mediated by IL-3 or IGF-1 in Baf-3 cells. Cell Death Differ 6: 290-296, 1999.

16. Lee $\mathrm{BH}$ and Ruoslahti E: Alpha5beta1 integrin stimulates Bcl-2 expression and cell survival through Akt, focal adhesion kinase, and $\mathrm{Ca}^{2+} /$ calmodulin-dependent protein kinase IV. J Cell Biochem 95: 1214-1223, 2005

17. Shaw RJ and Cantley LC: Ras, PI(3)K and mTOR signalling controls tumour cell growth. Nature 441: 424-430, 2006.

18. Abe M, Suzuki K, Inagaki O, Sassa S and Shikama H: A novel MPL point mutation resulting in thrombopoietin-independent activation. Leukemia 16: 1500-1506, 2002.

19. Yang J, Wu LJ, Tashino S, Onodera S and Ikejima T: Protein tyrosine kinase pathway-derived ROS/NO productions contribute to $\mathrm{G} 2 / \mathrm{M}$ cell cycle arrest in evodiamine-treated human cervix carcinoma HeLa cells. Free Radic Res 44: 792-802, 2010.

20. Cheng Y, Qiu F, Ye YC, Tashiro S, Onodera S and Ikejima T: Oridonin induces $\mathrm{G} 2 / \mathrm{M}$ arrest and apoptosis via activating ERK-p53 apoptotic pathway and inhibiting PTK-Ras-Raf-JNK survival pathway in murine fibrosarcoma L929 cells. Arch Biochem Biophys 490: 70-75, 2009.

21. Chen SC, Chen CH, Chern CL, Hsu LS, Huang YC, Chung KT and Chye SM: p-Phenylenediamine induces p53-mediated apoptosis in Mardin-Darby canine kidney cells. Toxicol In Vitro 20: 801-807, 2006.

22. Chen SC, Chen CH, Tioh YL, Zhong PY, Lin YS and Chye SM: Para-phenylenediamine induced DNA damage and apoptosis through oxidative stress and enhanced caspase- 8 and -9 activities in Mardin-Darby canine kidney cells. Toxicol In Vitro 24 1197-1202, 2010

23. Huang YC, Hung WC, Kang WY, Chen WT and Chai CY: p-Phenylenediamine induced DNA damage in SV-40 immortalized human uroepithelial cells and expression of mutant p53 and COX-2 proteins. Toxicol Lett 170: 116-123, 2007

24. Pettit GR, Hoard MS, Doubek DL, Schmidt JM, Pettit RK, Tackett LP and Chapuis JC: Antineoplastic agents 338: The cancer cell growth inhibitory. Constituents of Terminalia arjuna (Combretaceae). J Ethnopharmacol 53: 57-63, 1996

25. Zhu HJ, Wang JS, Guo QL, Jiang Y and Liu GQ: Reversal of P-glycoprotein mediated multidrug resistance in K562 cell line by a novel synthetic calmodulin inhibitor, E6. Biol Pharm Bull 28: 1974-1978, 2005.

26. Haendeler J,Zeiher AM and Dimmeler S: Vitamin C and E prevent lipopolysaccharide-induced apoptosis in human endothelial cells by modulation of Bcl-2 and Bax. Eur J Pharmacol 317: 407-411, 1996.

27. Ernst O, Zor T. Linearization of the bradford protein assay. J Vis Exp 38 (Pt II): 1918, 2010.

28. Balmain A, Gray J and Ponder B. The genetics and genomics of cancer. Nat Genet 33 (Suppl): 238-244, 2003.

29. Hanahan D and Weinberg RA: The hallmarks of cancer. Cell 100 $57-70,2000$

30. Hahn WC and Weinberg RA: Modelling the molecular circuitry of cancer. Nat Rev Cancer 2: 331-341, 2002.

31. Sun SY, Hail N Jr and Lotan R: Apoptosis as a novel target for cancer chemoprevention. J Natl Cancer Inst 96: 662-672, 2004.

32. Chen S, Xu Y, Xu B, Guo M, Zhang Z, Liu L, et al: CaMKII is involved in cadmium activation of MAPK and mTOR pathways leading to neuronal cell death. J Neurochem 119: 1108-1118, 2011

33. Arbon KS, Christensen CM, Harvey WA and Heggland SJ: Cadmium exposure activates the ERK signaling pathway leading to altered osteoblast gene expression and apoptotic death in Saos-2 cells. Food Chem Toxicol 50: 198-205, 2012.
34. Habib GM: Arsenite causes down-regulation of Akt and c-Fos, cell cycle dysfunction and apoptosis in glutathione-deficient cells. J Cell Biochem 110: 363-371, 2010.

35. Kelsh MA, Alexander DD, Kalmes RM and Buffler PA: Personal use of hair dyes and risk of bladder cancer: a meta-analysis of epidemiologic data. Cancer Causes Control 19: 549-558, 2008.

36. McFadden JP, White IR, Frosch PJ, Sosted H, Johansen JD and Menne T: Allergy to hair dye. BMJ 334: 220, 2007.

37. Atukeren P, Yavuz B, Soydinc HO, Purisa S, Camlica H, Gumustas MK and Balcioglu I: Variations in systemic biomarkers of oxidative/nitrosative stress and DNA damage before and during the consequent two cycles of chemotherapy in breast cancer patients. Clin Chem Lab Med 48: 1487-1495, 2010.

38. Zeraatpishe A, Oryan S, Bagheri MH, Pilevarian AA, et al: Effects of Melissa officinalis L. on oxidative status and DNA damage in subjects exposed to long-term low-dose ionizing radiation. Toxicol Ind Health 27: 205-212, 2011.

39. Reddy PH: Amyloid precursor protein-mediated free radicals and oxidative damage: implications for the development and progression of Alzheimer's disease. J Neurochem 96: 1-13, 2006

40. Curtin JF, Donovan M and Cotter TG: Regulation and measurement of oxidative stress in apoptosis. J Immunol Methods 265: 49-72, 2002.

41. Chan PH: Reactive oxygen radicals in signaling and damage in the ischemic brain. J Cereb Blood Flow Metab 21: 2-14, 2001

42. Ling YH, Liebes L, Zou Y and Perez-Soler R: Reactive oxygen species generation and mitochondrial dysfunction in the apoptotic response to Bortezomib, a novel proteasome inhibitor, in human H460 non-small cell lung cancer cells. J Biol Chem 278 33714-33723, 2003.

43. Qiu JH, Asai A, Chi S, Saito N, Hamada H and Kirino T: Proteasome inhibitors induce cytochrome $c$-caspase-3-like protease-mediated apoptosis in cultured cortical neurons. J Neurosci 20: 259-265, 2000.

44. Chiarugi P and Cirri P: Redox regulation of protein tyrosine phosphatases during receptor tyrosine kinase signal transduction. Trends Biochem Sci 28: 509-514, 2003.

45. Baselga J and Arteaga CL: Critical update and emerging trends in epidermal growth factor receptor targeting in cancer. J Clin Oncol 23: 2445-2459, 2005.

46. Khosravi-Far R, Solski PA, Clark GJ, Kinch MS and Der CJ Activation of Rac1, RhoA, and mitogen-activated protein kinases is required for Ras transformation. Mol Cell Biol 15: 6443-6453, 1995.

47. Chen YR, Wang W, Kong AN and Tan TH: Molecular mechanism of $c$-Jun N-terminal kinase-mediated apoptosis induced by anticarcinogenic isothiocyanates. J Biol Chem 273: 1769-1775, 1998.

48. Wu K, Zhao Y, Li GC and Yu WP: $c$-Jun N-terminal kinase is required for vitamin $\mathrm{E}$ succinate-induced apoptosis in human gastric cancer cells. World J Gastroenterol 10: 1110-1114, 2004.

49. Wang TH, Wang HS and Soong YK: Paclitaxel-induced cell death: where the cell cycle and apoptosis come together. Cancer 88: 2619-2628, 2000.

50. Sánchez-Pérez I, Martínez-Gomariz M, Williams D, Keyse SM and Perona R: CL100/MKP-1 modulates JNK activation and apoptosis in response to cisplatin. Oncogene 19: 5142-5152, 2000.

51. Matsui T and Rosenzweig A: Convergent signal transduction pathways controlling cardiomyocyte survival and function: the role of PI3-kinase and Akt. J Mol Cell Cardiol 38: 63-71, 2005.

52. She QB, Solit DB, Ye Q, O'Reilly KE, Lobo J and Rosen N: The BAD protein integrates survival signaling by EGFR/MAPK and PI3K/Akt kinase pathways in PTEN-deficient tumor cells. Cancer Cell 8: 287-297, 2005.

53. Finucane DM, Bossy-Wetzel E, Waterhouse NJ, Cotter TG and Green DR: Bax induced caspase activation and apoptosis via cytochrome $c$ release from mitochondria is inhibitable by Bcl-xL. J Biol Chem 274: 2225-2233, 1999.

54. Budihardjo I, Oliver $H$, Lutter $M$, Luo $X$ and Wang $X$ : Biochemical pathways of caspase activation during apoptosis. Ann Rev Cell Dev Biol 15: 269-290, 1999.

55. Desagher S and Martinou JC: Mitochondria as the central control point of apoptosis. Trends Cell Biol 10: 369-377, 2000. 